\title{
Occurrence of Lucilla scintilla (R.T. Lowe, 1852) and Lucilla singleyana (Pilsbry, 1890) in the Czech and Slovak Republics - with remarks how to distinguish these two non-native minute snails
}

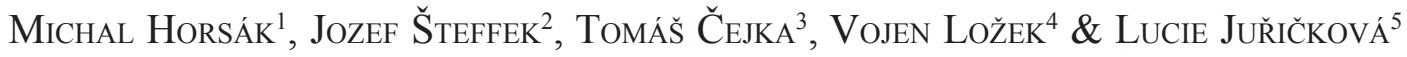 \\ ${ }^{I}$ Department of Botany and Zoology, Masaryk University, Kotlářská 2, CZ-61137 Brno, Czech Republic, e-mail: horsak@sci.muni.cz \\ ${ }^{2}$ Institute of Forest Ecology of the Slovak Academy of Sciences, Šturrova 2, SK-96053 Zvolen, Slovakia and Department of Applied \\ Ecology, Faculty of Ecology and Environmental Science, Technical Univerzity in Zvolen, T. G. Masaryka 24, SK-96053 Zvolen, \\ Slovakia; e-mail: steffekjozef@yahoo.com \\ ${ }^{3}$ Institute of Zoology, Slovak Academy of Sciences, Dúbravská cesta 9, SK-84104 Bratislava, Slovakia; e-mail: tomas.cejka@savba.sk \\ ${ }^{4}$ Institute of Geology, Academy of Science of the Czech Republic, Rozvojová 269, CZ-16500 Prague 6, Czech Republic \\ ${ }^{5}$ Department of Zoology, Faculty of Science, Charles University, Viničná 7, CZ-12844 Prague 2, Czech Republic; e-mail: lucie. \\ jurickova@seznam.cz
}

Horsák M., ŠTeFFeK J., ČEJKA T., LoŽEK V. \& JuŘIČKovÁ L., 2009: Occurrence of Lucilla scintilla (R.T. Lowe, 1852) and Lucilla singleyana (Pilsbry, 1890) in the Czech and Slovak Republics - with remarks how to distinguish these two non-native minute snails. - Malacologica Bohemoslovaca, 8: 24-27. Online serial at $<$ http://mollusca.sav.sk>18-June-2009.

Previously only one species of the genus Lucilla was reported from the Czech and Slovak Republics. Since this taxon is currently considered as two distinct species (L. singleyana and L. scintilla), a revision of older Czech and Slovak records was needed. The revision of available voucher material yielded findings of both species in Slovakia, contrary to the Czech Republic where only L. scintilla has been found outdoors. Distribution and detail location of known outdoor records and identification remarks, supplemented with pictures of the shells, are included in this paper.

Keywords: Lucilla, Czech Republic, Slovakia, distribution, identification characters

\section{Introduction}

Lucilla scintilla and L. singleyana are minute, blind and subterranean snails living in rootlet holes and shrinkage cracks down to depths of a metre from the surface (KERNEY 1999). They have flat shells with a width up to $3 \mathrm{~mm}$. They are native in North America; to Europe they were probably introduced in the second half of the 20th century. First few findings came usually from anthropogenic habitats (KERNEY et al. 1983). The first record from Great Britain, for example, was reported in 1975, and there are no fossil records (KERNEY 1999). These older records were referred to only one species, mostly determined as Helicodiscus singleyanus (Pilsbry, 1890), since these two taxa were not considered as distinct species. This was because PilsBRy (1948) reduced H. inermis H.B. Baker, 1929, currently synonymised with $L$. scintilla, to a subspecies of $H$. singleyanus. KERNEY et al. (1983) mentioned that most of European populations belong to $H$. singleyanus inermis, which matches with the description of shell characters in his book, whereas the drawing of the shell resembles rather L. singleyana. Therefore, it is probable that both taxa were already present in Europe, just not distinguished reliably, which was also the situation of the Czech and Slovak records. Some malacologists consider the systematic status of these two taxa in Europe still a bit ambiguous and not completely clear (e.g. WeLter-Schultes 2009), however in many recent publications these two taxa are mentioned as distinct species (e.g. FALKNER et al. 2002,
Nekola 2002, Lori \& Cianfanelli 2007, Jungbluth \& von KNORRE 2008).

In this paper we revised all voucher material from the Czech and Slovak Republics in order to find out which of these two non-native species actually occur here. The second purpose is to serve readers pictures of shells and to point out the main diagnostic characters to help with identification of these species.

\section{Results}

A revision of available voucher material yielded outdoor findings of both species in Slovakia, contrary to the Czech Republic where only L. scintilla has been found at three outdoor sites (Fig. 1). Two records of L. scintilla came also from Slovakia where also L. singleyana was found at three sites (Fig. 1). At one site (site no. 1 for both species) these two species co-occurred.

List of known sites with the occurrence of Lucilla scintilla and L. singleyana

Data in the list are as follows: site number, state, geographical co-ordinates, code of the mapping grid for faunistic mapping (according to EHRENDORFER \& HAMANN 1965), name of the nearest settlement, description of the site, elevation (m a.s.1.), number of individuals (ex.), date of investigation, name of investigator. References of already published records are given. All samples were revised by 


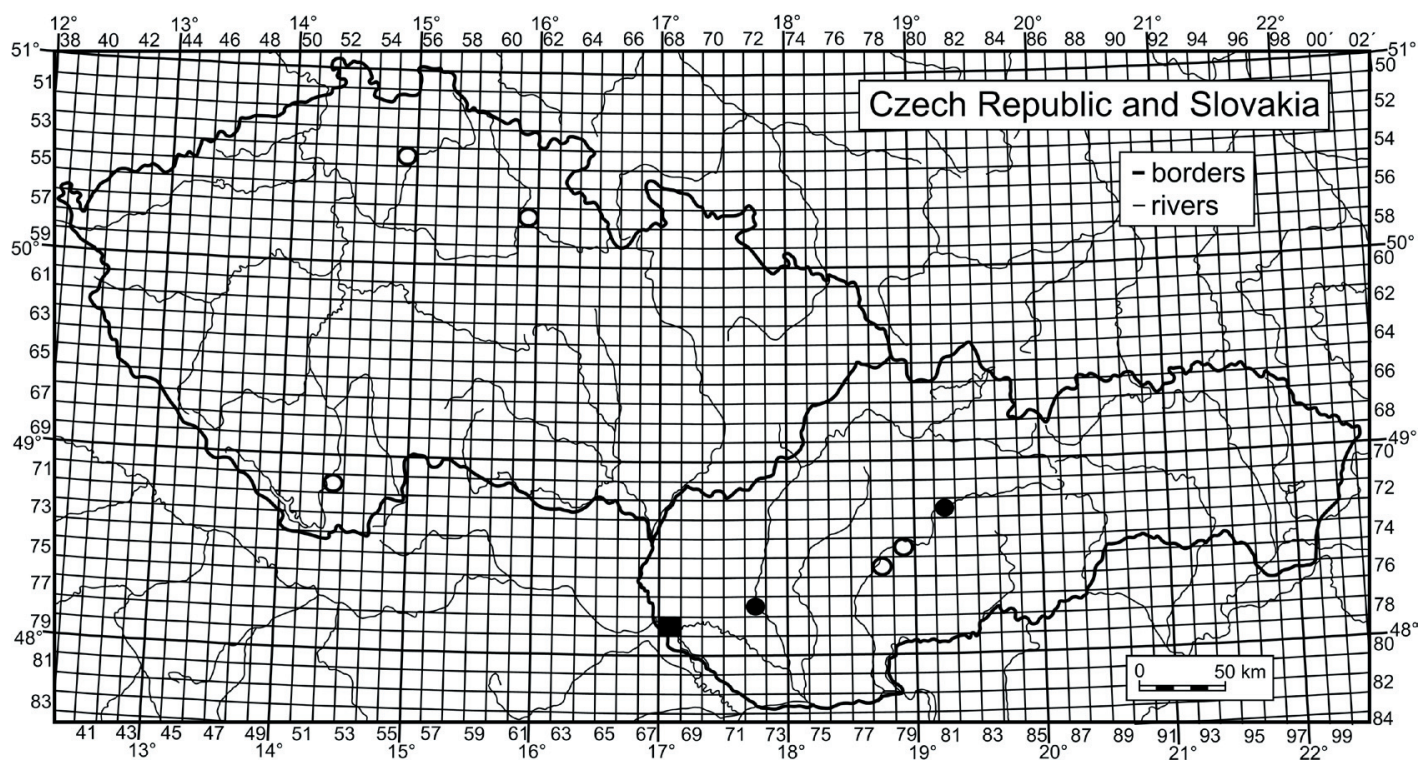

Fig. 1. Known outside records of Lucilla scintilla (empty dots) and L. singleyana (black dots) in the Czech and Slovak Republics. Co-occurrence of both species is marked by black square.

M. Horsák except two records of V. Ložek. Voucher specimens are deposited in personal collections of particular investigators.

\section{Lucilla scintilla}

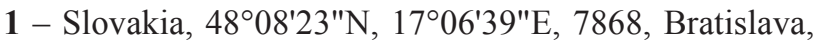
a flood debris of the Danube River, 135 m, 2 ex., 20 Mar 1999, T. Čejka, originally published as Helicodiscus (Hebetodiscus) singleyanus inermis (С̆ ЕJKA 2000); 2 - Slovakia, 48³1'39.44"N, 1751'51.47"E, 7479, Sklené Teplice, a spa - a travertine below the church, $352 \mathrm{~m}, 1$ ex., 10 Jul 2007, J. Šteffek; 3 - Slovakia, 48²8'17.66"N, $18^{\circ} 43^{\prime} 36.80^{\prime \prime E}, 7578$, Žarnovica, a flood debris of the Hron River, 216 m, 2 ex., 11 Apr 1996, J. Šteffek, originally published as L. singleyana (ŠTEFFEK 2003); 4 - Czech Republic, Bohemia, 50¹3'39"N, 1550'40"E, 5761, Hradec Králové, Věkoše Cemetery, 235 m, 2 ex., 3 May 1999, 2 ex., 8 May 2001, L. Juřičková, originally published as Helicodiscus inermis (JuŘIČKová 1998); 5 - Czech Republic, Bohemia, 50³1'06"N, 1457'01"E, 5455, Mnichovo Hradiště, a flood debris of the Zábrtka stream, $245 \mathrm{~m}, 1$ ex., 1987, V. Ložek, originally published as Helicodiscus inermis (LožEK 1988); 6 - Czech Republic, Bohemia, $48^{\circ} 51^{\prime} 10^{\prime \prime} \mathrm{N}, 14^{\circ} 22^{\prime} 14^{\prime \prime E}, 7152$, Zlatá Koruna, a food debris of the Vltava River, 480 m, 1 ex, 2006, V. Ložek.

\section{Lucilla singleyana}

1 - Slovakia, 480 $08^{\prime} 23^{\prime \prime N}, 17^{\circ} 06^{\prime} 39^{\prime \prime} \mathrm{E}, 7868$, Bratislava, a flood debris of the Danube River, 135 m, 5 ex., 20 Mar 1999, T. Čejka, originally published as Helicodiscus (Hebetodiscus) singleyanus inermis (ČEJKA 2000); 2 - Slovakia, $48^{\circ} 15^{\prime} 32.27^{\prime \prime} \mathrm{N}, 17^{\circ} 47^{\prime} 14.50^{\prime \prime E}$, 7772, Králová pri Senci, a deposit of the reservoir, $123 \mathrm{~m}, 1$ ex., 16 May 2004, J. Šteffek \& B. Bielčík; 3 - Slovakia, 4845'19"N, 19¹6'19"E, 7281, Driekyňa stream, near Slovenská Lupča, a deposit of the stream, 408 m, 1 ex., 8 Jun 2003, J. Šteffek.

\section{Identification remarks}

These two species are conchologically rather similar; however they bear many reliable and unequivocal characters. Most of these characters have been described already by Pilsbry (1948). They differ in shell size and shape, and especially in colour of periostracum (= conchyolin layer). The most prominent character is colour of periostracum (Figs 2-4): L. singleyana being uncoloured (Fig. 2) and $L$. scintilla being distinctly yellowish (Fig. 3). L. singleyana can grow up higher; shell width is up to $3 \mathrm{~mm}$ contrary to L. scintilla whose shell can only slightly exceeds $2 \mathrm{~mm}$. This species has a slightly conical shell spire contrary to L. singleyana that has a completely flat spire. Additional characters are a bit more closed and deeper umbilicus of $L$. scintilla contrary to opened and shallower umbilicus of $L$. singleyana (cf. Figs 2 and 3). PILsBry (1948) also thought of surface microsculpture as another difference between these species; in his conception subspecies. L. singleya$n a$ is under a higher magnification closely covered with microscopic spiral lines which are nearly or entirely missing in L. scintilla. However, in our material this character appeared to be hard to track and rather variable among specimens of both species. Since the interspecies variation of the surface microsculpture was one of the reasons why Pilsbry (1948) reduced these taxa to one species it is questionable if this is a good and useful character for reliable identification. Even though, our material was limited we recommend not using this character especially if there are several other more obvious and reliable differences.

In the course of reviewing this paper we found out that several authors may have a problem with distinguishing snails of the genus Lucilla from those belonging to the genus Hawaiia. They used characters on male genitalia or on radula to distinguish between Lucilla spp. and Hawaiia minuscula (Binney, 1840) (e.g. Dомокоs \& Majoros 2008). However, these species clearly differ in the shape of their shells and mainly in surface microstructures. $\mathrm{Lu}$ cilla spp. have a smooth shell surface only with very fine 

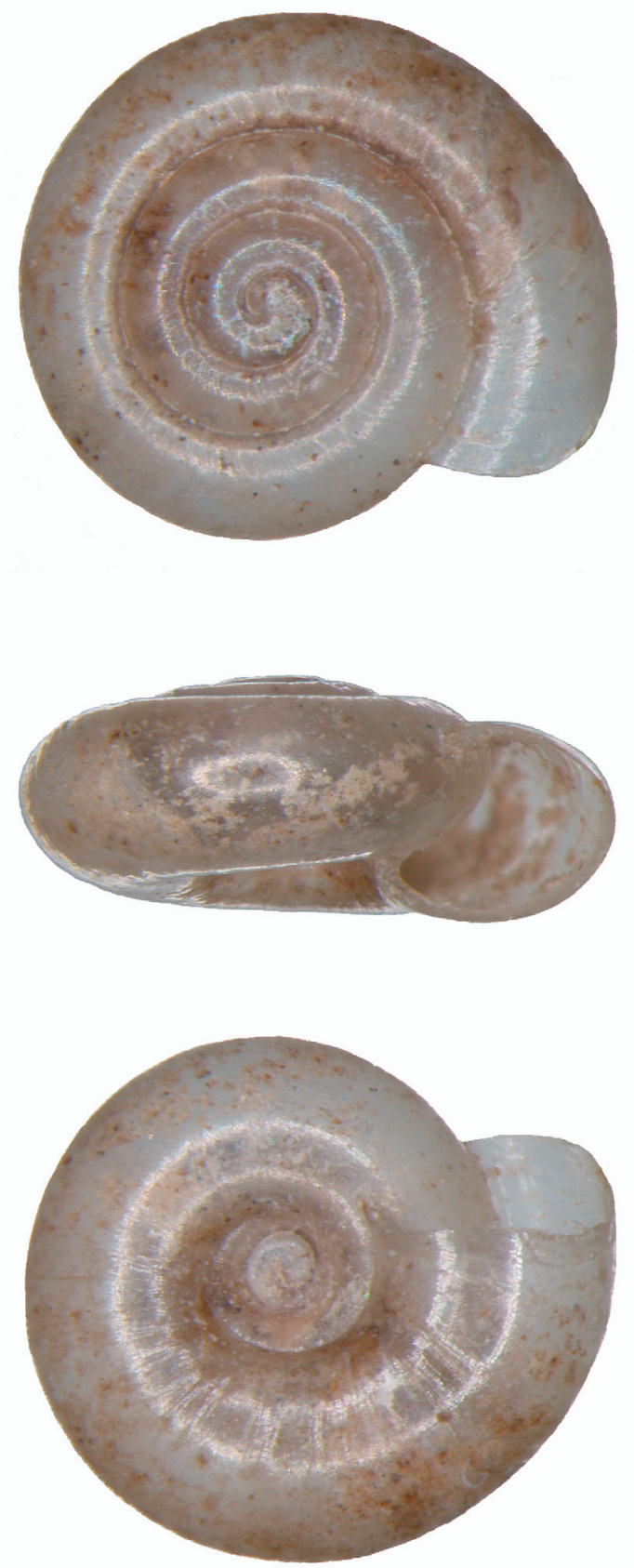

Fig. 2. Shell of Lucilla singleyana from site no. 1. Width: 2.3 $\mathrm{mm}$, high: $1.0 \mathrm{~mm}$.

spiral lines (mentioned above) and it is rather glossy. In contrast $H$. minuscula has nearly regular transversal striae crossed by prominent spiral striae and the surface is not glossy. These identification characters were for example mentioned by МÁcHA (1988) who also supplemented his paper by informative SEM photographs of shell surfaces; the same was published by Lori \& Cianfanelli (2007). Further, the entire shell of $H$. minuscula is more thick and with a significantly deeper suture. Finally, up till now $H$. minuscula has been reported in Europe only from greenhouses (KERNEY et al. 1983, HoRSÁK et al. 2004).

\section{Discussion}

Sporadic records, mostly as empty shells sieved from the flood debris of rivers in Britain, were considered as results
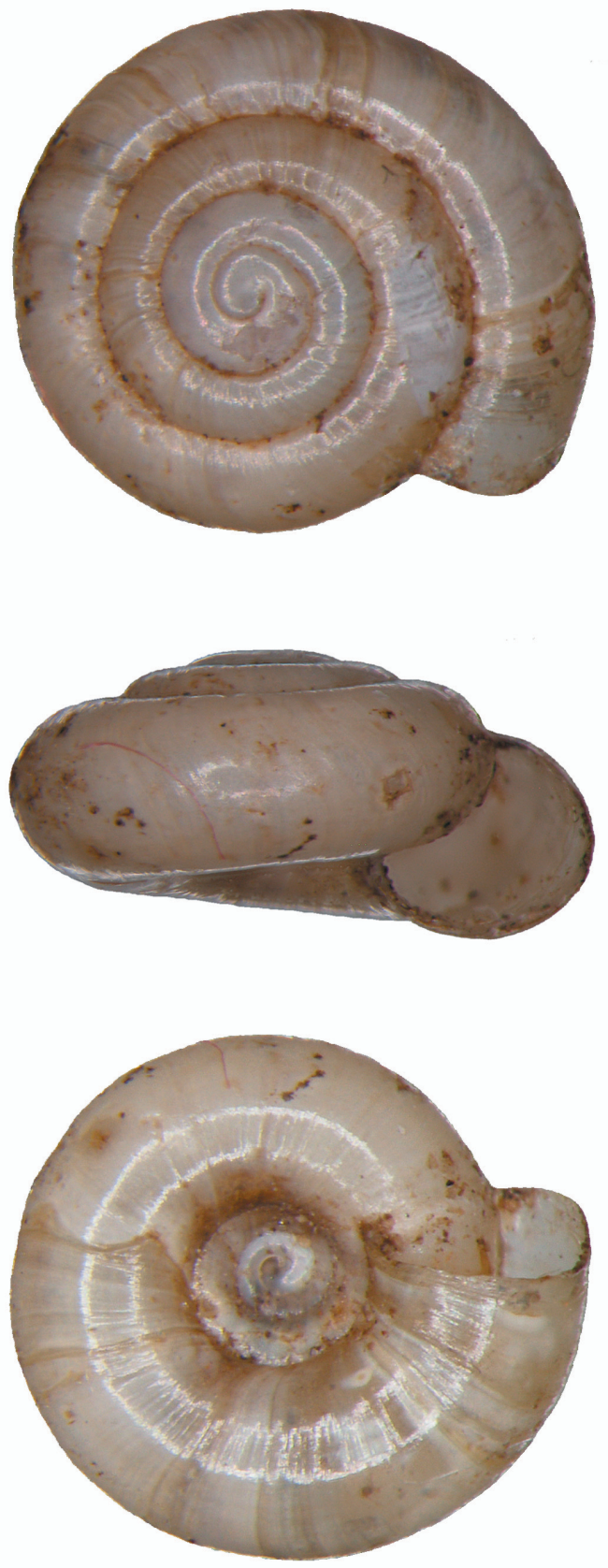

Fig. 3. Shell of Lucilla scintilla from site no. 4. Width: $2.05 \mathrm{~mm}$, high: $1.00 \mathrm{~mm}$.

of cryptic life mode of these species (KeRney 1999). A very similar situation was documented also based on our material. Almost all our shells were empty; however, they have an intact periostracum. These species are probably more common in both Czech Republic and Slovakia than one could expect solely based on known records. Several Czech and Slovak records have also origin in greenhouses as these snails are probably rather common there (e.g. FlASAR 1978, HorsáK et al. 2004), but these findings were not revised and considered in this study. Here it is worth mentioning that $L$. singleyana has already been found in the Czech Republic in greenhouses of the Masaryk University in Brno (2004, M. Ruprechtová lgt., M. Horsák det.). Therefore it seems probable that this species is also living outside in the Czech Republic. 


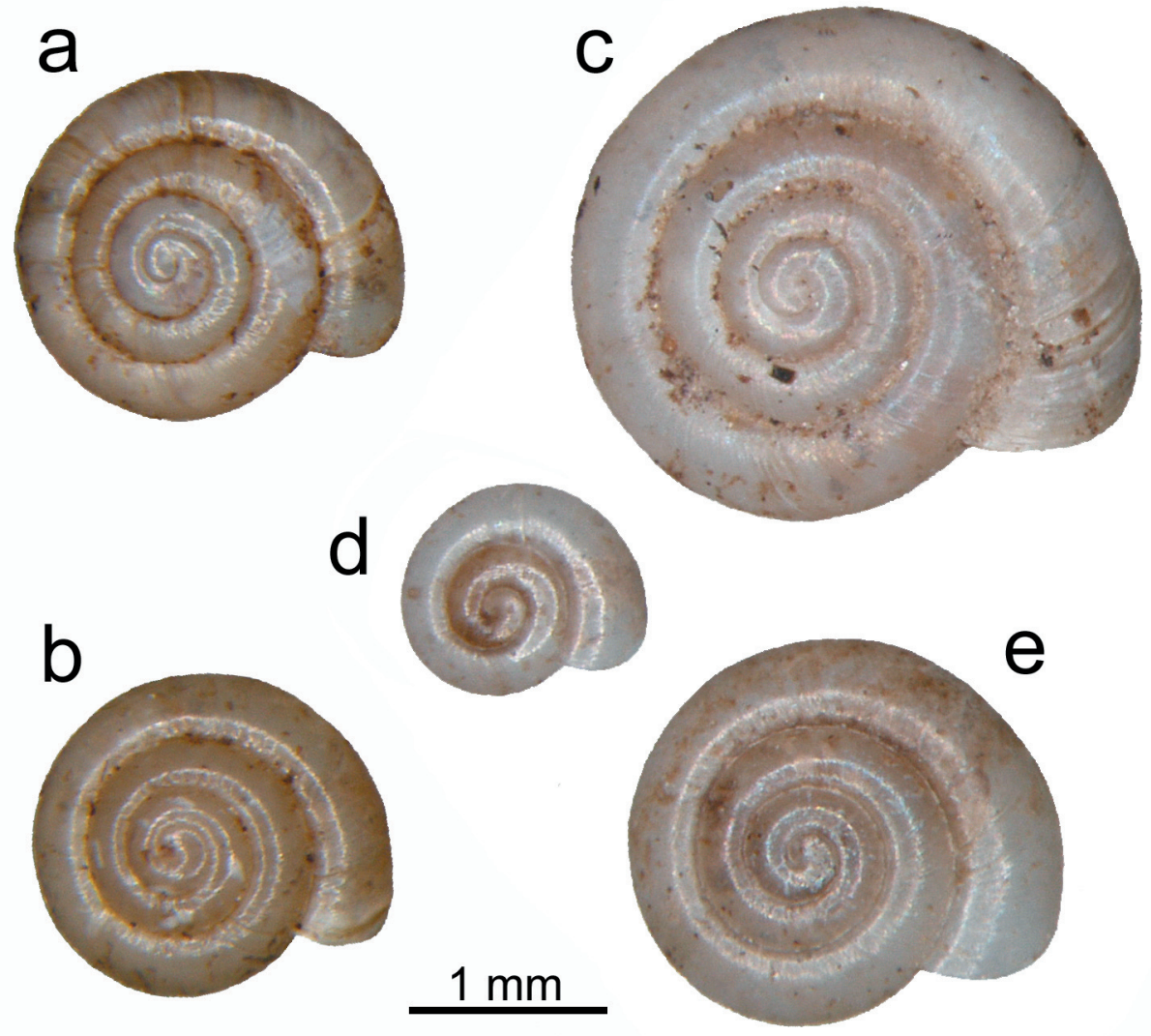

Fig. 4. Direct comparison of shell size, shape and colour of Lucilla scintilla (a-b) and L. singleyana (c-e). Location: a, site no 4; b-e, site no. 1 .

\section{Acknowledgements}

Funding comes from grants IAA601630803, MSM 0021622416, MSM 0021620828, VEGA 1/7079/07, VEGA 1/4353/07, VEGA 1/0026/08, and VEGA 2/0130/07.

\section{References}

ČEJKA T., 2000: First record of the land snail Helicodiscus (Hebetodiscus) singleyanus inermis H.B. Baker, 1929 (Gastropoda, Punctidae) in Slovakia. - Biologia (Bratislava), 55: 475-476.

Dомокоs T. \& MAJoros G., 2008: A Lucilla singleyana (Pilsbry, 1889) (Gastropoda: Helicodiscidae) - „talajlakó laposcsigácska” - elöfordulása hazánkban, különös tekintettel a Körös-Maros közére (Magyarország és Románia) [The Occurrence of Lucilla singleyana (Pilsbry, 1889) (Gastropoda: Helicodiscidae) in Hungary, and especially at the Kõrös-Maros interfluves in Hungary and Romania]. - Malacological Newsletter, 26: 19-32.

EHRENDORFER F. \& HAMANN U., 1965: Vorschläge zu einer floristischen Kartierung von Mitteleuropa. - Berichte der Deutschen Botanischen Gesellschaft, 78: 35-50.

FALKNER G., RipKen T.E.J. \& FALKNeR M., 2002: Mollusques continentaux de France. Liste de Référence annotée et Bibliographie. - Patrimoines naturels, 52: 1-350.

FlaSAR I., 1978: Nový druh měkkýše v našich sklenících [New snail species in our greenhouses]. - Živa, 5/1978: 182.

Horsák M., DvořÁk L. \& JuŘičKovÁ L., 2004: Greenhouse gastropods of the Czech Republic: current stage of research. - Malacological Newsletter, 22: 141-147.

JungBluth J.H. \& KNORRE Von D., 2008: Trivialnamen der Landund Süßwassermollusken Deutschlands (Gastropoda et Bivalvia). - Mollusca, 26(1): 105-156.

JuŘIČKovÁ L., 1998: Měkkýši Hradce Králové [Mollusca of Hradec Králové, East Bohemia, Czech Republic]. - Acta Musei Reginaehradecensis s. A., 26: 101-172.
KeRney M., 1999: Atlas of the land and freshwater molluscs of Britain and Ireland. - Harley Books, Colchester, 261 pp.

Kerney M.P., Cameron R.A.D. \& Jungbluth J.H., 1983: Die Landschnecken Nord- und Mitteleuropas. - Verlag Paul Parey, Hamburg und Berlin, 384 pp.

Lori E. \& Cianfanelli S., 2007: Studio sulla presenza e distribuzione di Molluschi terrestri e d'acqua dolce alieni nel territorio della provincia di Pistoia. Relazione finale per la Provincia di Pistoia, pp. 97. - Unpublished final report available at http://www.provincia.pistoia.it/AreeProtette/LR56 2000_MolluschiEduliCrostaceiAcquaDolce/MolluschiAlieniProvinciaPistoia.pdf

LožEK V., 1988: Měkkýši a změny prostředí [Molluscs and environmental changes]. - Památky a príroda, 13(9): 547-553.

MÁcha S., 1988: Další nový druh měkkýše v našich sklenících Hawaia minuscula (Binney, 1840) sic! [Other new mollusc species in our greenhouses - Hawaia minuscula (Binney, 1840)]. - Čas. Slez. Muz. Opava (A), 37: 63-64.

Nekola J.C., 2002: Effects of fire management on the richness and abundance of central North American grassland land snail faunas. - Animal Biodiversity and Conservation, 25(2): 5366.

Pilsbry H.A., 1948: Land Mollusca of North America (north of Mexico). Vol. II. Part II. - Academy of Natural Science of Philadelphia. Philadelphia, PA., 520 pp.

ŠTeFfeK J., 2003: Význam náplavov pre výskum diverzity mäkkýšov na príklade rieky Hron v Žarnovici [Importance of flood debris for the research of mollusc diversity: a case study from the river of Hron near Žarnovice town]. - Acta Facultatis Ecologiae (Zvolen), 10, Suppl. 1: 213-215.

Welter-Schultes F., 2009: AnimalBase Project Group, 2005. AnimalBase. Early zoological literature online. Worldwide web electronic publication. - http://www.animalbase.uni-goettingen.de/zooweb/servlet/AnimalBase/home/species?id=3162, last modification 26-02-2009. 